(4) To promote scientific education by encouraging the support of universities and other institutions where the bounds of science are extended, or where new applications of science are devised.

During the first stage of the existence of the guild, the public activity of the committee was limited, by reasons of policy, because at the moment of the inception of the movement the attention of the country, and especially of Parliament, was so deeply engrossed in the fiscal problem that no other question, however important, was likely to receive due attention.

The Royal Society and British Association were founded for the promotion of natural knowledge; the Society of Arts for the encouragement of arts, manufactures, and commerce. The Science Guild, though in sympathy with these objects, is not identical in aim with any existing society. The promotion of natural knowledge is outside its sphere. Its purpose is to stimulate, not so much the acquisition of scientific knowledge, as the appreciation of its value, and the advantage of employing the methods of scientific inquiry, the study of cause and effect, in affairs of every kind. Such methods are not less applicable to the problems which confront the statesman, the official, the merchant, the manufacturer, the soldier, and the schoolmaster, than to those of the chemist or the biologist; and the value of a scientific education lies in the cultivation which it gives of the power to grasp and apply the principles of investigation employed in the laboratory to the problems which modern life presents in peace or war.

Communications may be addressed to the honorary secretary of the British Science Guild, I6 Penywern Road, London, S.W.

SIR WILLIAM WHARTON, K.C.B., F.R.S. WILLIAM JAMES LLOYD WHARTON, second Court Judge of York, was born in London on March 2, 1843. Educated at Burney's Academy, Gosport, he entered the Royal Navy in August, 1857 , on board H.M.S. Illustrious, then recently commissioned as a training ship for naval cadets, stationed at Portsmouth. Passing with great credit out of the Illustrious, he was appointed in April, I858, midshipman of H.M.S. Euryalus, on board which ship H.R.H. Prince Alfred (afterwards Duke of Edinburgh) was also serving. In November, I860, being appointed to H.M.S. Jason, commissioned for service on the North American and West Indian stations, he was lent to H.M.S. St. George, employed on fishery duties in Newfoundland during the summer of 186r. On completing his time as midshipman he passed his examination in seamanship for the rank of lieutenant on January 13, $186_{3}$. Whilst still serving in the Jason he was made acting lieutenant of that ship on October 26,1864 , and at the close of the year, on the Jason returning to England to pay off, he at last had the opportunity to pass the examinations in gunnery and navigation necessary to qualify him for the rank of lieutenant. In these he acquitted himself brilliantly, being confirmed in his rank March I5. 1865 . In December of that year he was awarded the Beaufort testimonial for passing the best examination of the year in mathematics, nautical astronomy, and navigation.

In the meantime, in July, I 865 , he had been appointed to H.M.S. Gannet, a sloop commissioned partly for the general duties of the fleet, and partly for surveying service on the North American and West Indian stations, but acting entirely under the orders of the Commander-in-Chief. In that ship he acquired his first experience in the work to which his life was afterwards devoted, receiving the commendation of the Board of Admiralty for the zeal displayed by him on the work performed in the Bay of Fundy. The Gannet paid off in November, 1868.

The interest of the Commander-in-Chief, ViceAdmiral Sir James Hope, having been aroused by the ability and industry shown by Lieut. Wharton whilst serving in the Gannet, as well as by the distinction which he had gained in passing his examinations, when the admiral hoisted his flag at Portsmouth he offered to Wharton the appointment of flag lieutenant. The hydrographer had meanwhile promised to submit his name as second lieutenant of H.M.S. surveying vessel Newport; Wharton consequently considered that his services were pledged to the Surveying Service, although by adhering to it he was fully aware that he would sacrifice the prospect of certain promotion at the end of three years, but this he was prepared to do. Sir James Hope, however, took another view, and speedily arranging matters with the hydrographer, Wharton was appointed as his flag lieutenant on March I, I869. Whilst so employed he wrote "The History of H.M.S. Victory," which still commands a steady sale to the public, the proceeds being devoted to the R.N. Seamen's and Marines' Orphans' Home, Portsmouth.

In November, 1870, H.M.S. Urgent being fitted out to convey astronomers to the neighbourhood of Gibraltar to observe the forthcoming total eclipse of the sun, Sir James Hope gratified his flag lieutenant by permitting him to accompany the expedition as first lieutenant of the ship. He was promoted to commander March 2, 1872 , on Sir J. Hope striking his flag, and the following month saw him appointed to the command of H.M. surveying vessel Shearwater, first on the Mediterranean station and afterwards on the east coast of Africa. In the Mediterranean his work was chiefly distinguished by a valuable contribution to science in the form of an investigation of the surface and undercurrents in the Bosphorus, setting at rest the many controversies respecting the exhaustless flow of water from the Black Sea to the Sea of Marmora by proving that an undercurrent existed as strong as that on the surface, but which invariably flowed in exactly an opposite direction. His report, which was officially published, may be considered as prescribing the method for similar inquiries. Whilst at Rodriquez, in the South Indian Ocean, he took part in observing the transit of Venus in 1874 . The Shearwater was paid off in July, 1875 , and in June the following year he commissioned the Fawn for surveying service in the Mediterranean, Red Sea, and east coast of Africa. Starting with a staff of officers most of whom were wholly inexperienced, Commander Wharton set himself to train them after his own ideals, and succeeded in imbuing his assistants with something of his untiring energy and love of the work. Whilst exacting the utmost that each individual was capable of giving to the service, he exercised unremitting patience and forbearance, and throughout a prolonged commission of four and a half years endeared himself to all who had the happiness to serve under him. He was sympathetic and considerate towards both officers and men, and entered heartily into all schemes for their recreation when opportunity offered. This commission of the Fawn was perhaps one of the most successful, as it certainly was one of the happiest, ever spent by a surveying vessel in modern times. The last two years were occupied with the survey of the Sea of Marmora, an excellent piece of work for which he and his officers received an expression of their Lordships' approbation.

On January 29, 1880, Wharton was promoted to captain, and the Fawn paid off at Malta at the end of the year.

No, ז876, VOL. 72 ] 
An interval of leisure then followed, during which Captain Wharton published " Hydrographical Surveying." $\mathrm{He}$ expresses himself with characteristic modesty in the preface, but it was at once universally recognised as the standard work on the subject, and has continued to be so considered to the present time, being used both in our own and in foreign navies.

In March, I882, he commissioned H.M.S. Sylvia for surveying service in the River Plate and Straits of Magellan. It was already an open secret that he was destined to succeed Captain Sir Fred. Evans as Hydrographer to the Admiralty when that officer should retire. In December, I882, he successfully observed the transit of Venus for the second time. The anxieties of two seasons in the inhospitable climate and dangerous waters of the western part of the Straits of Magellan told upon Wharton considerably, and at this time he aged much in appearance. But, full of energy as ever, the work was pushed on rapidly in spite of the hardships and difficulties that had to be encountered, with the result that the survey was completed within the allotted time, and on returning to Montevideo in March, 1884 , he left the stip and proceeded to England by mail steamer to assume the duties of hydrographer, being appointed as such on August r, 1884, at an age younger than that of any officer who had held that responsible position. This closed his career afloat.

Wharton's administration of the hydrographic department of the Admiralty continued uninterruptedly for twenty years with constantly increasing credit, and to the great advantage of our own Navy as well as to the whole maritime world. This period covered the enormous expansion that took place both in the personnel and materiel of the fleet, causing corresponding accessions to the labour of departmental work; during the same period the number of chart plates was largely increased, and the number of charts printed annually for the fleet and for sale to the public multiplied three-fold.

Gifted with an extraordinary capacity for work, he never spared himself; the sound judgment, breadth of view, and wide scientific attainments constantly brought to bear upon the infinite variety of subjects with which he was daily called upon to deal secured for him the respect and confidence of successive Boards of Admiralty. An especial characteristic was the readiness with which the mass of information he had acquired on all sorts of subjects was available on the spur of the moment. As ex-officio member of the Meteorological Council, he attended its meetings assiduously and rendered valuable service to the advancement of ocean meteorology.

His personal interest in the surveying service was unceasingly manifested in the voluminous semi-official correspondence he maintained with the officers in command of surveys. Scientific subjects of whatever nature bearing on hydrography always claimed his attention, and in 1886 he was elected a Fellow of the Royal Society, serving on its council from 1888 to r889, again from $\mathrm{I} 895$ to $\mathrm{I} 897$, and being again elected in 1904 was a member until his death.

As Fellow of the Royal Astronomical Society, as well as of the Royal Geographical Society, as vicepresident of the latter and member of numerous committees, he did work only less important than his official work at the Admiralty. His first contribution to the literature of the Royal Society was the investigation of the great waves produced by the eruptions of Krakatoa in 1882 , which had been begun by the late Sir Frederick Evans and left unfinished at his death. In $\mathrm{I} 893$ he edited the journal of Captain Cook during his first voyage round the world; at the meeting of the British Association at Oxford in I894 he presided over
Section E. Various contributions to NATURE appeared from time to time from his pen, the investigation of the origin and formation of coral reefs being a subject of especial interest to him. He advanced a theory, based upon the results of surveys of large numbers of these reefs, that the effect of wave action was mainly accountable for the striking uniformity of depth so frequently met with over the interior of coral banks in the open ocean, showing that wave action in open oceans extended to greater depths than was hitherto considered possible.

As a member of the coral reef committee of the Royal Society, he was largely responsible for the selection of Funafuti as the atoll to be investigated by sounding and boring operations, and he was instrumental in securing the cooperation of the Admiralty in the work, which has produced such valuable results.

He was keenly interested in the project for Antarctic exploration, but more particularly in its bearing upon terrestrial magnetism, and he took a very active part as a member of the joint committee of the Royal and Royal Geographical Societies appointed to organise it.

$\mathrm{He}$ was placed on the retired list in $189 \mathrm{I}$, in accordance with the regulation respecting non-service at sea. Promoted to Rear-Admiral on January I, 1895 , on the Queen's birthday that year he was nominated as C.B. On the occasion of the Diamond Jubilee in I897 he was created K.C.B.

On July 3r, I904, Sir William Wharton resigned the office of hydrographer. For some years previously he had suffered much inconvenience and pain owing to an injury to his right wrist received whilst serving in the Shearwater; for this and other causes he determined to relinquish the appointment. In July last, after a visit to Aix-les-Bains, he accepted with some hesitation the reiterated invitation to go out to South Africa with a party of members of the British Association, and he presided over Section E at Cape Town. Unfortunately he fell ill on the return journey from the Victoria Falls, and could not return to England as he intended, with his friends, in the Armadale Castle. His illness, which was at first thought to be a chill, proved to be enteric fever complicated with pneumonia, and although no effort was spared to effect his recovery he died at the observatory at Cape Town on September 29, where he was the guest of his old and valued friends Sir David and Lady Gill. He was buried at the Naval Cemetery at Simon's Town on October I with full naval honours, H.M. the King being represented by the Commander-in-Chief of the station. He was married, in I880, to Lucy Georgina, daughter of Mr. Edward Holland, of Dumbledon, in Gloucestershire, and by her, who survives him, he had two daughters and three sons, two of whom are now serving in H.M. Navy.

A. M. F.

\section{GEORGE BOWDLER BUCKTON, F.R.S.}

$\mathrm{NE}$ of the most energetic and laborious, as well as one of the oldest of our British entomologists, Mr. George Bowdler Buckton, died on September 25 in his eighty-eighth year. Although he was always interested in natural history, it is somewhat remarkable that, while many men take up the study of entomology in early life and abandon it later, all his important entomological work was executed late in life, and was carried on until a very short period before his death.

Mr. Buckton was born at Hornsey on May 24, 1818. $\mathrm{He}$ was privately educated, being debarred from entering a public school by an accident in boyhood which crippled him for life. 